\title{
DETECTION METHODS OF CARCINOGENS IN ESTUARIES: A REVIEW
}

\author{
A. MALAKAHMAD ${ }^{1}$, T.S. ABD MANAN ${ }^{1} \&$ S. SIVAPALAN ${ }^{2}$ \\ ${ }^{1}$ Civil Engineering Department, Universiti Teknologi PETRONAS, Malaysia. \\ ${ }^{2}$ Management and Humanities Department, Universiti Teknologi PETRONAS, Malaysia.
}

\begin{abstract}
About $70 \%$ of all cancer deaths occur in low- and middle-income countries. Deaths from cancer worldwide are projected to continue to rise over 13.1 million by 2030. Research indicates that estuaries such as rivers and lakes contain various carcinogenic compounds. The carcinogens are transported from the release points to the intake points. To avoid this phenomenon from happening, fast and accurate detection of carcinogen concentrations in water is crucial. This paper presents a review of various detection methods of carcinogenic compounds in watercourses via biological, physical and chemical approaches. Descriptions of the biological procedures such as chromosomal aberration, Micronucleus assay, Ames test, Salmonella assay, SOS chromotest, Comet assay and organic extraction of XAD with blue rayon are discussed. Physical approaches have the integration of automated detections with science and engineering approaches, particularly sensors. Automated optical sensors, submersible ultraviolet fluorometer sensors, photoelectrochemical sensors with the detection of DNA damage and trihalomethanes sensors for the detection of carcinogenic compounds are also reviewed. Chemical approaches consist of the analysis of extraction, purification and identification of organic contaminants using high-technology equipments such as the atomic absorption spectrophotometer, high-performance liquid chromatography and gas chromatography-mass spectrometry. Carcinogens can be identified accurately using an appropriate method chosen from the available alternatives. The evaluations of detection methods presented in this review are based on advantages and disadvantages, accuracy, speed and time factor of methods and experimental procedures by previous scholars. This review contributes as guidance to readers on existing methods within different fields and their exclusive applications on different types of carcinogens in water.
\end{abstract}

Keywords: detection methods limitations, water-borne carcinogens, water quality.

\section{INTRODUCTION}

Cancer accounted for around $13 \%$ of all deaths in 2008. About $70 \%$ of all cancer deaths occurred in low- and middle-income countries. Deaths from cancer worldwide are projected to continue to rise over 13.1 million by 2030. Carcinogens are potential compounds that can cause cancer to humans, based on certain concentrations or periods of time [1,2]. Water-borne carcinogens such as heavy metal ions, polycyclic aromatic hydrocarbons (PAHs), N-nitroso compounds, mycotoxins and heterocyclic amines (HCAs) are carcinogenic upon consumption [3-8].

Malaysia's 30 million people generate about six million tons or approximately three million cubic meters of sewage every year, at the cost of US\$ 0.3 billion, for management and treatment and to discharge the treated wastewater into the rivers $[9,10]$. Appropriate management of wastewater is thus of great concern at wastewater treatment plants [11-14], as about 98\% of Malaysia's fresh water supply comes from surface water. Domestic wastewater is wastewater originating from residential areas. It is mainly from the substances of human metabolism and household activities. Over $90 \%$ of carcinogenic loading comes from domestic areas. Raw surface water becomes contaminated because of excessive and random discharge of wastewater, directly from households to drains, and finally into rivers, with minimal or no treatment. These areas can achieve loading values greater than industrial zones, with standard loading over discharging rate of more than $10^{9} \mathrm{~L} /$ day.

A strong correlation between cancer and the presence of pollutants in wastewater has been proclaimed in previous studies [15-18]. The deterioration of water quality creates a hazard to public 
health through poisoning or the spread of non-communicable diseases such as cancer $[9,10,19,20]$. Previous reports indicate that estuaries such as rivers and lakes contain various carcinogenic compounds [9-76]. The carcinogens are transported from release points to intake points. To avoid this phenomenon from happening, fast and accurate detection of carcinogenic concentrations in water is crucial. This paper presents a review of various detection methods of carcinogenic compounds in watercourses via biological [22-53], physical [54-66] and chemical approaches [67-76].

According to National Cancer Research Institute, cancer is a term used for diseases that involve abnormal cells dividing without control and able to invade other tissues. The genetic material (DNA) of a cell can become damaged or changed, producing mutations that affect normal cell growth and division. These cells may form a mass of tissue called tumor [77].

Tumors can be benign or malignant. Benign tumors are not cancerous, can often be removed and do not spread to other parts of the body. Meanwhile, malignant tumors are cancerous, can invade nearby tissues and spread to other parts of the body. The spread of cancer from one part of the body to another is called metastasis. Cancer happened when altered or damaged DNA occurs to such extent that cells become transformed and begin to exhibit abnormal malignant properties [1,2,77,78].

There are more than 100 different types of cancer. Cancers are named based on the type of the cell or organ in which they have invaded. Generally, cancer types can be grouped into main categories such as carcinoma, sarcoma, leukemia, lymphoma and myeloma, and central nervous system cancers $[1,2,77,78]$.

Carcinogen is an agent that will produce cancer via carcinogenesis. Carcinogenesis is a cancer development process in any affected cells that involves mechanisms such as genotoxicity carcinogenesis (GCsis) and non-genotoxicity carcinogenesis (xGCsis). GCsis indicates primary mechanism of producing cancer by directly altering the genetic material of the target cells. xGCsis represents secondary mechanism of producing cancer not related to direct gene damage but will disrupt cellular metabolic process by altering gene expressions [1,2,77,78]. Carcinogens that exhibit non-genotoxicity mechanism have been shown to act as tumor promoters (1,4-dichlorobenzene), endocrine modifiers (17 $\beta$-estradiol), receptor mediators (2,3,7,8-tetrachlorodibenzo- $p$-dioxin), immunosuppressants (cyclosporine) or inducers of tissue-specific toxicity and inflammatory responses (metals such as arsenic and beryllium) [77-79]. Regardless of primary (GCsis) or secondary cancer mechanisms (xGCsis), the end product of carcinogenesis is an altered or damaged DNA that leads to abnormal cell growth. Figure 1 summarizes cancer and its mechanism based on biological terms accordingly.

Although many biologist and researchers are very keen in using the 'non-genotoxic carcinogen' term, the term itself tends to give false impression that carcinogens shown to be negative for mutagenicity in a series of test systems and might be harmless to humans [80]. Moreover, the carcinogens classification by world authorized bodies [81,82] (IUARC and WHO) are only referring to definitely carcinogenic (Group 1), probably carcinogenic (Group 2A), possibly carcinogenic (Group 2B), not classifiable as carcinogenic to humans and probably not carcinogenic to humans (Group 4). There are practices more or less same, found in carcinogens classification by Globally Harmonized System [83] and US National Toxicology Program by US Department of Health and Human Services [84]. None of the published legal classifications are referring carcinogens as genotoxicity carcinogens or non-genotoxicity carcinogens. Undeniably, non-genotoxic mechanism of carcinogens is widely studied around the world to understand the cells engineering system. Therefore, the authors suggested that the specific term for carcinogens and their mechanisms (carcinogenesis) should be critically justified and applied accordingly.

Mutations are the indications of the presence of carcinogenic compounds. Mutation effects in biological organisms vary. They are chromosomal aberrations (CAs), growth inhibition and teratogenic 


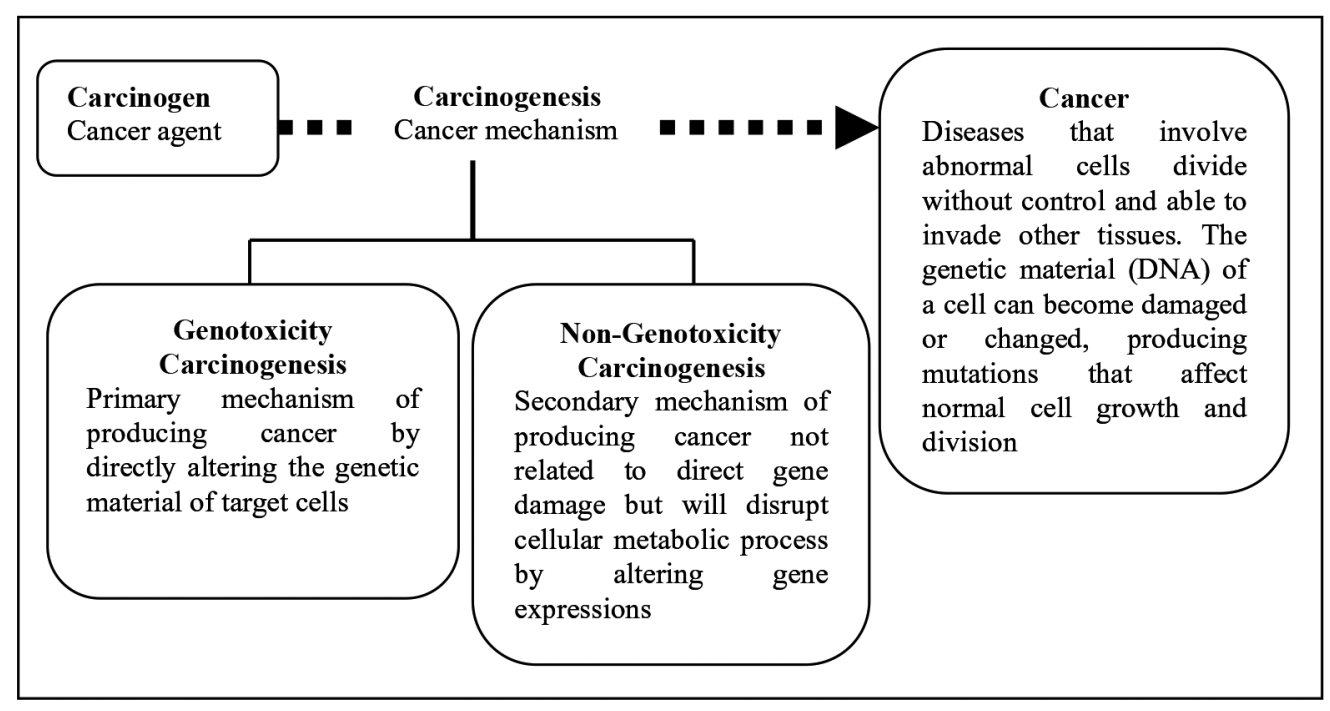

Figure 1: Diagram on cancer and its mechanism.

effects [22]. These effects can only be detected through the application of biological approaches [22-24]. The CA [23-34], Micronucleus (MN) assay [25], Ames test [35-38], Salmonella assay [39-42], SOS chromotest [43-45], Comet assay [46-50] and organic extraction of XAD with blue rayon [51,52] are discussed. These bioassays serve as a biomarker for the presence of carcinogens in the water. As cancer is often linked to DNA damage, they are also highly reliable in the estimation of the toxicity level or carcinogenic potential of a compound [53].

Physical approaches have the integration of automated detections with science and engineering approaches, particularly sensors. Automated detection is an application of computer programming basis and the fundamentals of electrical and electronic engineering studies [54-66]. Sensors are handy and have a relatively higher speed and sensitivity compared with biological approaches [54-66]. However, sensors application in the detection of carcinogens is very limited. They are exclusively made for specific types of carcinogens only. Therefore, the development of sensors is not only subtle and extensive, but also extortionate. The history of automated detections and various types of sensors such as automated optical sensors [63], submersible ultraviolet fluorometer sensors [64], photoelectrochemical sensors with the detection of DNA damage [65] and trihalomethanes (THMs) sensors [66] for the detection of carcinogenic compounds are reviewed.

Chemical elements, compounds and mixtures are physically and chemically unique in its properties. Some of them are carcinogenic in nature. The physical properties are melting point, electrical conductivity, color, density, odor, boiling point, thermal conductivity, hardness, ionization energy, refractive index, atomic radius, allotropes, ductility and malleability. Meanwhile, the chemical properties refer to the material's property or characteristics toward a chemical reaction [67]. Chemical methods are based on the general physical and chemical properties of chemical compounds. These are precise and fast approaches to detect the carcinogens present in water and wastewater. Extraction, purification and identification of organic contaminants analysis demand the use of high-technology equipments such as atomic absorption spectrophotometer (AAS) [68,69], highperformance liquid chromatography (HPLC) [70-72] and gas chromatography-mass spectrometry (GC-MS) [73-76]. The accuracy is highly guaranteed. Although they are costly, they are financially 
reasonable in the long run. Carcinogens can be identified accurately using an appropriate method chosen from the available alternatives. Good maintenance and regular calibration are necessary.

The evaluation of detection methods presented in this review are based on advantages and disadvantages, accuracy, speed and time factor of methods and experimental procedures by previous scholars. This review contributes as guidance to readers on the existing methods within different fields, and their exclusive applications on different types of carcinogens in water.

\section{HISTORY OF GENETIC INHERITANCE, MUTATION AND CANCER}

In the mid-19th century, Mendel made a great discovery in genetics. His genetic investigations involved an experiment of approximately 30,000 pea plants of eight generations. The pea plants were bred and cross-bred using different characteristics. He found that a tall plant bred to a short one will always produce tall offspring. The phenotypes of these bred pea plants will never blend to medium size. Moreover, the breed of these offspring produced three tall and one short offspring. These experiments showed that the characteristics of a plant depend on the inherited genes (genotype). Darwin's theory red herrings the fundamentals of genetic inheritance. Darwin's theory states that an organism's phenotype changes according to the adaptation of its environment, while the characteristics of new organisms were blended as they passed to the offspring producing a new organism, which explains the theory of the evolution of humans [21].

Mutation can alter genomes randomly. Cancer cells often exhibit mutated or aberrantly structured chromosomes. Mutations in genes may produce cancer genes. These genes can be inherited. The gene carrier will survive. However, if the carrier marries another carrier, one of the children will suffer from cancer [21].

A mutagen is an agent or substance that is able to cause different types of mutations. Mutagens can be biological, chemical or physical agents. Biological mutagens are commonly from viruses and metabolic activities of organisms and organelles. Organelles are the components inside the cells of organisms, while chemical mutagens are from hazardous chemicals such as nitrous acid and hydrogen peroxide. Physical agents are radiations from sun, cellular telephone, radioactive radon gas and electromagnetic waves from electric power lines [1,2,21].

A carcinogen is an agent that induces abnormal patterns of growth in cells, directly leading to cancer [22]. Although not all of the mutations may cause cancer, it is undeniable that there is a strong correlation between the ability of a substance to induce mutations, and its ability to induce cancer $[1,2,13-33]$.

\section{BIOLOGICAL DETECTION METHODS}

Carcinogenic compounds can cause mutation. Therefore, mutations are the indications of the presence of carcinogenic compounds. The result of mutation is CAs and it can be detected through the application of detection methods using biological approaches. They are CA, MN assay, Ames test, Salmonella assay, SOS chromotest, Comet assay and organic extraction of XAD with blue rayon.

\subsection{Anaphase/metaphase analyses and micronucleus analyses}

CAs or abnormalities in chromosomes can be detected microscopically via Micronucleus Analyses and Anaphase/metaphase analyses (A/M analyses) [22]. A/M analyses are commonly applied in the Allium cepa (onion) test.

The common onion test $(2 n=16)$ was first introduced by Albert Levar in 1938 . The chromosomes are large and easily observed compared with other plants. It makes a very convenient test system for estimating harmful effects of chemicals or environmental pollutants in wastewater. In the presence 
of genetic hazard pollutants, these aberrant cells can be observed in anaphase and metaphase stages [24]. A MN is a small nucleus that is formed during mitosis or meiosis [22,25].

\subsubsection{Applications}

There are numerous genotoxicity studies using the A. сера. Water samples tested are commonly from sewage effluent [26], industrial effluent [27], pharmaceutical effluent [28], industrial wastewater [29], surface water [30] as well as wastewater sludge [31]. Zeng et al. [32] studied the pollution levels of three rivers passing through Fuzhou city.

A survey by Grant and Owens [33] showed that the Crepis capillaris $(2 \mathrm{n}=6)$ bioassay is an excellent plant bioassay for assessing chromosome damage induced by chemicals and environmental pollutants [33]. The genotoxicity of municipal landfill leachate was carried out by Sang and Li [34] via the Vicia faba bioassay. The results showed that leachate may pose a genotoxic risk to bioorganisms [34]. Table 1 summarizes the CA assays of indicator plant species.

\subsubsection{Evaluation}

Analyses and A/M analyses are highly in demand due to its simple preparation method as well as the ease of availability of materials and equipments. However, the evaluation of CAs is time consuming and facilitated by the use of indicator plant species that have a small number of large chromosomes [21,22], which include A. cepa [26-31], Tradescantia sp. [32], C. capillaris [33] and V. faba [34].

\subsection{Ames test}

The Ames test was introduced in 1975, by Bruce Ames [35], a bacterial geneticist. It involves the growing of bacteria on agar plates and comparing natural mutation rates to mutation rates of bacteria

Table 1: Tracer concentrations.

\begin{tabular}{|c|c|c|c|}
\hline Analyses & $\begin{array}{l}\text { Transducing } \\
\text { elements }\end{array}$ & $\begin{array}{l}\text { Types of water } \\
\text { sample }\end{array}$ & Bio-monitoring protocols \\
\hline $\mathrm{A} / \mathrm{M}$ analyses & Allium сера & $\begin{array}{l}\text { Effluent: sewage, } \\
\text { industrial, } \\
\text { pharmaceutical, } \\
\text { wastewater, surface } \\
\text { water, wastewater } \\
\text { sludge }\end{array}$ & $\begin{array}{l}\text { Mitotic index and } \\
\text { percentage of root } \\
\text { length } \\
{[26-31]}\end{array}$ \\
\hline MN analyses & Tradescantia sp. & Rivers in China & $\begin{array}{l}\text { MN frequencies scoring } \\
\text { procedure [32] }\end{array}$ \\
\hline $\begin{array}{l}\mathrm{A} / \mathrm{M} \text { analyses } \\
\text { and } \mathrm{MN} \text { analyses }\end{array}$ & Crepis capillaris & $\begin{array}{l}\text { Water contained } \\
\text { insecticide at } \\
\text { different } \\
\text { concentrations }\end{array}$ & $\begin{array}{l}\text { MN frequencies scoring } \\
\text { procedure [33] }\end{array}$ \\
\hline $\begin{array}{l}\mathrm{A} / \mathrm{M} \text { analyses } \\
\text { and } \mathrm{MN} \text { analyses }\end{array}$ & Vicia faba & $\begin{array}{l}\text { Municipal landfill } \\
\text { leachates }\end{array}$ & $\begin{array}{l}\text { Mitotic index and MN } \\
\text { frequencies scoring } \\
\text { procedure [34] }\end{array}$ \\
\hline
\end{tabular}


exposed to potentially mutagenic compounds or samples. In this test, an extract of rat liver called S-9 mix containing microsomal enzymes and cofactors is often added to the bacteriological medium.

The medium contains genetically modified Salmonella typhimurium strains. The presence of mutations in the histidine genes, causing defects in a metabolic pathway leading to the production of histidine, allows positive selection of histidine revertants on minimal agar plates lacking histidine. Only mutants that are able to restore this function are able to form colonies on such plates. Usually, the plates containing the tested compound and tester bacteria are incubated for $48 \mathrm{~h}$ after which bacterial colonies are counted [35].

\subsubsection{Application}

The mutagenic and anti-mutagenic activities of 42 synthetic flavones were evaluated via the Ames test by Beudot et al. [37]. The tested flavones included twenty-three 3-nitroflavones, eighteen 3 -aminoflavones and the 3-chloroflavone. It was found that the mutagenicity of the 3-aminoflavones required the presence of metabolic activation. The 3-amino derivatives were more mutagenic than the 3-nitro counterparts [37]. Total and fractionated organic extracts from industrial effluents and Labe river water were tested for mutagenicity effect using the Ames test with TA98 strain and its YG derivatives (YG1021, YG1024 and YG1041), and cytogenetic analysis with human peripheral lymphocytes in vitro.

The mutagenicity effect was found to be dose dependent. The mutagenicity effect was also detected in polar acidic and polar basic fractions, in fractionated samples. The cytogenetic effect in human peripheral lymphocytes in vitro was not significant. Thus, in this research, the increase in CAs was not clearly dose dependent and may reflect more on the clastogenic effects [38].

\subsubsection{Evaluation}

The Ames test is excellent for testing mutagenic activity of defined chemicals under laboratory conditions. However, the limitations of the assay are the survival of tester strains, which are sensitive to water samples containing high salt concentrations. In addition, the sensitivity of the test may be too low for the detection of low amounts of mutagens in environmental samples. The tester strain is also potentially pathogenic bacterium that can cause diarrhea and food poisoning.

\subsection{Salmonella assay}

The Salmonella assay is widely used for genotoxicity detection in water samples. It is based on the detection of histidine-independent revertants in selected strains after exposure to mutagens with or without activation enzymes. Some researchers combined the Salmonella assay with other biological tests such as the $\mathrm{MN}$ test and $\mathrm{A} / \mathrm{M}$ analyses for a good correlation and interpretation of results $[39,40]$.

\subsubsection{Application}

Lemos et al. [41] studied the genotoxic potential of a river basin under the impact of agricultural, urban and industrial activities under the influence of climatic variation. Investigation was performed on different strains of the Salmonella assay. The upper river basin showed low pollution, mainly from small farms. Other results showed high concentration of mutagenic responses at the Sinos River in the middle and lower reaches, influenced by large discharge from domestic sewers and industries [41].

The mutagenicity of aluminum oxide nanomaterials (NMs) $\left(\mathrm{Al}_{2} \mathrm{O}_{3}-30 \mathrm{NM}\right.$ and $\left.\mathrm{Al}_{2} \mathrm{O}_{3}-40 \mathrm{NM}\right)$ was carried out using the Ames test by Balasubramanyam et al. [42]. The bacterial strains used 
were S. typhimurium TA100, TA1535, TA98, TA97a and TA102, in the presence and absence of the S9 mixture. However, no significant changes were found in the number of revertant colonies (with or without $\mathrm{S} 9$ mixture) at different concentrations of $\mathrm{Al}_{2} \mathrm{O}_{3}-30 \mathrm{NM}$ and $\mathrm{Al}_{2} \mathrm{O}_{3}-40 \mathrm{NM}$ tested, compared with the $\mathrm{Al}_{2} \mathrm{O}_{3}$-bulk and control. The findings suggested that $\mathrm{Al}_{2} \mathrm{O}_{3} \mathrm{NMs}$ were invalid of any size- and concentration-dependent mutagenicity, compared with the $\mathrm{Al}_{2} \mathrm{O}_{3}$-bulk and control. It shows that Salmonella sp. might probably be resistant to these compound materials [42].

\subsubsection{Evaluation}

Salmonella sp. has resistance to certain compound materials. Thus, Salmonella assay is not prominent for certain compound materials, and it is yet to be ascertained.

\subsection{SOS chromotest}

The SOS chromotest is an alternative to the conventional Ames test. SOS chromotest (on Escherichia coli $\mathrm{PQ} 37)$ is measured by the determination of the $\beta$-galactosidase enzyme activity.

\subsubsection{Application}

The microplate version of the SOS chromotest was developed as a sensitive screening of genotoxins in water samples [43] such as HCAs [44]. This test version provides qualitative (the observable changes in color gradient) and quantitative measurements (spectrophotometry with calculation of commonly accepted metrics unit) for the tested samples [48]. Jolibois and Guerbet [45] evaluated water samples via the combination of the SOS chromotest (on E. coli PQ37) and the Salmonella fluctuation test on different strains of $S$. typhimurium with or without metabolic activation.

The water samples were taken from the Rouen University Hospital, the Rouen wastewater (hospital effluents mixed with urban and industrial effluents), the wastewater treatment plant (hospital, industrial and domestic), and the Grand Couronne wastewater treatment plant (domestic wastewater). The results showed that samples collected in domestic wastewater were slightly genotoxic in comparison to the samples collected in mixed wastewater [47].

\subsubsection{Evaluation}

The accuracy and sensitivity of this biological assay is comparable to the Ames test. It is less time consuming and widely used for genotoxicity monitoring in water samples. However, E. coli PQ37 is one of the strains of pathogenic bacteria. Therefore, the SOS chromotest needs a special safety culture bacteria laboratory to avoid dangerous effects when dealing with bacteria.

\subsection{Comet assay}

The Comet assay is also called a single-cell gel electrophoresis. This technique was developed by Swedish researchers Ostling and Johansson [46] in 1984. It is a sensitive and rapid technique for quantifying and analyzing DNA damage in individual cells. It has been applied in both animal eukaryotes and plant cells studies.

On the contrary, it has also been used to monitor DNA repair in cancer research such as the evaluation of genotoxicity and effectiveness of chemoprevention in living cells [46]. Singh et al. [47] later modified this technique in 1988 and called it the alkaline Comet assay. The resulting image obtained resembles a 'comet' with a distinct head and tail. The head is composed of intact DNA, whereas the tail consists of damaged or broken pieces of DNA [47]. 


\subsubsection{Application}

Lemos et al. [48] conducted the comet assay in Tilapia rendalli fish of Lake Igapo II, Brazil. The results demonstrated that samples had significantly greater genotoxicity class 2 (medium damage) and class 3 (extensive damage) comets [48]. Rocha et al. [49] conducted in vitro comet assay with fish cells and in situ MN assay using erythrocytes from tilapia (Oreochromis niloticus) in Tiete River, Brazil. Results from the in vitro comet assay documented two sites near Spring and Billings reservoirs that showed strong genotoxicity.

For in situ MN assay, the fish collected from the Billings reservoirs revealed highest MN frequencies [49]. Summak et al. [50] conducted in vivo MN tests in Nile tilapias (O. niloticus) blood erythrocytes along the Nilufer Stream, Turkey. The results indicated that the stream was contaminated with potential genotoxic chemicals related with industrial, agricultural and domestic activities [50].

\subsubsection{Evaluation}

Theoretically, the comet assay can be used for all animal cells. Unfortunately, sometimes consistent data are not achieved. Human lymphocytes are the most reliable cells used for the comet assay. However, not all the damage to cells and organs are detectable using lymphocytes. In addition, lymphocytes are not reliable to study repair systems since repair damage is slow. The comet assay is not able to detect small DNA fragments (smaller than $50 \mathrm{~kb}$ ).

\subsection{Organic extraction with XAD and blue rayon}

Organic extraction in columns using XAD resins and blue rayon is a regularly applied method for genotoxic compounds in rivers that are contaminated with domestic sewage, due to the capability of adsorbing a class of mutagenic compounds such as PAHs and arylamines. Organic extraction in columns using XAD resin has shown positive results in literature when those extracts were tested and compared with the water sample using Salmonella assay [51,52].

\subsubsection{Application}

Kummrow et al. [51] analyzed a river under the influence of discharges of an azo-dye processing plant and a water reservoir contaminated with untreated domestic sewage by performing organic extraction in columns packed with XAD4 resin and with blue rayon. Results indicated that the mutagenicity of river water was much higher for both blue rayon and XAD4 extracts when compared with the water from the reservoir using Salmonella assay [51]. Oda et al. [52] conducted an experiment to understand the basis of human cytochrome P450 (CYP) and $N$-acetyltransferases in genotoxic activation of PBTA-4, PBTA-6, PBTA-7 and PBTA-8 and identified them as major mutagens in blue cotton/rayon-adsorbed substances collected at sites of municipal water treatment plants (WTPs) treating domestic wastewater and effluents from textile dyeing factories in several rivers in Japan [52].

\subsubsection{Evaluation}

The hanging technique using blue rayon specifically adsorbs mutagens with multicyclic planar structures. It has the advantage over most conventional methods of not having to bring large volumes of water back to the laboratory for extraction of organic materials. Blue cotton/rayon is adsorbed using blue rayon or blue cotton as an adsorbent. It can collect large quantities of unidentified chemicals. However, it has a disadvantage of not allowing quantitative analysis. 


\section{PHYSICAL DETECTION METHODS}

This part presents descriptions of selected detection and measurement methods of carcinogens in estuaries, via physical approaches, for the detection of carcinogenic compounds. They are automated optical sensors, submersible ultraviolet fluorometer sensors, photoelectrochemical sensors with the detection of DNA damage and THMs sensors.

\subsection{Automated system}

Ctesibius was the first automated system introduced in Egypt over two thousand years ago. It kept time by regulating the water level in a vessel [54]. Later, a variety of automatic devices have been implemented to accomplish tasks or for entertainment. The concept of the open-loop control was initiated in European countries around the 17th and 18th century [55].

The closed-loop control was the temperature regulator of a furnace and the centrifugal flyball that controlled the speed of steam engines, by regulating the amount of working fluid, as introduced by James Watt in 1788 [56].

Maxwell electromagnetic field equations were introduced by Maxwell in 1868 to explain instabilities exhibited by the flyball [57]. This demonstrated the importance and usefulness of mathematical models, mathematical control and systems theory. Control theory with new mathematical techniques made significant strides in the 1900s.

These developments in optimal control were followed in the 1950s, and progressively developed in 1970s. Although control theory is a form of electrical engineering, control engineering is also practiced as a part of mechanical engineering [58].

The applications of control systems have been merged in various research fields such as aerospace [59], data roadways [60], wireless sensors, [61] as well as in environmental studies, particularly for the detection of potential environmental pollutants [62-65].

The detection methods of environmental pollutants are the incorporation of sensor technology. A sensor or detector measures the selected pollutants and converts them into a signal that can be recorded by an observer or instrument. Calibration using known standards is usually implemented to maintain accuracy.

\subsection{Application}

Automated optical or electrochemical sensors consist of multi-parameter fiber for online water monitoring designed by Dybko [62] in 2009. The detected parameters are $\mathrm{pH}$, concentration of calcium ions and total concentration of heavy metals (cadmium, zinc, lead and mercury). This chemo-optical interface converts information on the water analytes into optical signals. The system accuracies are the $\mathrm{pH}$ sensor 0.04 , calcium sensor $0.1 \mathrm{pCa}$ and heavy metals ion's sensor $0.1 \mathrm{pMe}$ ( $\mathrm{p}$ refers to the power of the appropriate ion concentration). The system is capable of working continuously for 3 months of monitoring, without maintenance, with four measurements per day [62]. An automated optical sensor is favorable for general water monitoring practices based on the common environmental parameters.

The submersible ultraviolet fluorometer (EnviroFlu-HC, TriOS Optical Sensor) was developed for real-time measurement. It was tested in the coastal Mediterranean for the detection of PAHs. The PAHs standard solutions were a mixture of six compounds; anthracene, fluoranthene, fluorene, naphthalene, phenanthrene and pyrene, as well as individual solutions of naphthalene and phenanthrene (P98\%, Sigma-Aldrich). The standard solution of L-tryptophan (P98\%, Sigma-Aldrich) was employed for tryptophan-like material, whereas for humic-like and fulvic-like materials, standard 
solutions of Suwannee River humic $(2 \mathrm{~S} 101 \mathrm{H})$ and fulvic $(2 \mathrm{~S} 101 \mathrm{~F})$ acids were from the International Humic Substances Society. It was found that the EnviroFlu-HC was not strictly specific to PAHs, even though it exhibited the highest sensitivity for phenanthrene, but could respond to tryptophanlike materials as well as to humic substances. The EnviroFlu-HC is a worthy monitoring tool for environmental pollutants in coastal waters. However, the application should be combined with other fluorescence measurements so that information about the nature of the detected aromatic compounds can be improved [63].

Photoelectrochemical sensors with the detection of DNA damage induced by titanium dioxide and polystyrene nanoparticles were introduced by Ahmed et al. [64]. The sensor was made from a multilayer film prepared on a tin oxide nanoparticle electrode. The organic compounds and heavy metals represent genotoxic chemicals leading to two damaging mechanisms; DNA adducts formation and DNA oxidation. The DNA damage is detected via the change of photocurrent of the indicator. The DNA bases became more accessible to photoelectrochemical oxidation upon damage (oxidation), while it produced an increase in photocurrent. Both sensors displayed substantial photocurrent change after incubation in titanium dioxide or polystyrene solution in a time-dependent manner. According to the data, the damage of the DNA film was completed in $1 \mathrm{~h}$ in titanium dioxide or polystyrene solution. In addition, the titanium dioxide induced much more severe damage than polysterene. The results were verified independently by gel electrophoresis and UV-Visible spectrophotometry experiments. The photoelectrochemical reaction can be employed as a new and inexpensive screening tool for the rapid assessment of the genotoxicity of existing and new chemicals [64].

THMs form during the chlorination of water and wastewater. These compounds are considered as potential carcinogens in the National Primary Drinking Water Standards [65]. According to Kruger [66], the current methods of detecting THMs require skilled technicians to analyze, involve the use of hazardous chemicals and do not provide real-time THMs data to plant operators. Therefore, the WTP model was used to predict THMs formation during water treatment. Jar and chlorination tests were performed on water samples collected from lakes Pleasant, Saguaro and Bartlett to simulate a traditional WTP chlorinated under simulated distribution system conditions. The parameters that affect THMs formation were dissolved organic carbon, temperature, bromide, $\mathrm{pH}$ and chlorine. Formation of THMs after the jar tests was assessed by adding chlorine and measuring THMs after a $24 \mathrm{~h}$ chlorine contact time. The regulated THMs formed during chlorination ranged from 28 to $224 \mathrm{ppb}$. The THMs sensor consists of a wristwatch quartz tuning fork (QTF) with its tines bound together by a polymer wire that is selective to gas-phase THMs. Different concentrations of THMs produce different ranges of resonances in the QTF [66]. The list of automated detection approaches for carcinogens is summarized and shown in Table 2.

\subsection{Evaluation}

Carcinogens can be identified accurately using advanced sensors. An automated optical sensor is good for general water monitoring practice, based on common environmental parameters such as $\mathrm{pH}$, concentration of calcium ions and total concentration of heavy metal (cadmium, zinc, lead and mercury) [61]. The Submersible Ultraviolet Fluorometer is also called the EnviroFlu-HC, TriOS Optical Sensor. This sensor is applicable to marine water for the detection of PAHs, tryptophan-like material and fulvic-like materials [62]. The photoelectrochemical sensor, with the detection of DNA damage, can detect DNA damage via the change of the photocurrent of the indicator. Although its application is very time consuming, it is considered inexpensive in the long run, in comparison to the 
Table 2: The summary of physical approaches for carcinogens in estuaries.

\begin{tabular}{|c|c|c|c|c|}
\hline Sensors & Elements & Range & Indicator/standards & Software \\
\hline \multirow{2}{*}{$\begin{array}{l}\text { Automated } \\
\text { optical } \\
\text { [23] }\end{array}$} & $\mathrm{pH}$ & $\begin{array}{l}6.5-7.8 \\
7.7-9.4\end{array}$ & Bromothymol blue & \multirow[t]{2}{*}{$\begin{array}{r}\text { LabVIEW } \\
\text { software }\end{array}$} \\
\hline & $\begin{array}{l}\text { Calcium ions } \\
\text { Cadmium zinc } \\
\text { Lead } \\
\text { Mercury }\end{array}$ & $\begin{array}{l}10^{-5} \text { to } 10^{-2} \mathrm{M} \\
10^{-7} \text { to } 10^{-4} \mathrm{M}\end{array}$ & $\begin{array}{l}\text { Chlorophosphonazo III } \\
\text { 4-(2-pirydylazo) } \\
\text { resorcinol }\end{array}$ & \\
\hline \multirow{2}{*}{$\begin{array}{l}\text { Submersible } \\
\text { ultraviolet } \\
\text { fluorometer } \\
{[24]}\end{array}$} & $\begin{array}{l}\text { Phenanthrene } \\
\text { Naphthalene }\end{array}$ & $\begin{array}{l}0.6 \mu \mathrm{g} \mathrm{L}^{-1} \\
17 \mu \mathrm{g} \mathrm{L}^{-1}\end{array}$ & $\begin{array}{l}\text { Phenanthrene } \\
\text { Naphthalene }\end{array}$ & \multirow[t]{2}{*}{$\begin{array}{l}\text { TriOS MSDA- } \\
\text { XE 8.0.0 } \\
\text { software }\end{array}$} \\
\hline & $\begin{array}{c}\text { Total dissolved } \\
\text { solid + PAHs }\end{array}$ & $\begin{array}{l}0.005 \text { to } \\
0.5 \mu \mathrm{g} \mathrm{L}-1\end{array}$ & $\begin{array}{l}\text { Anthracene, } \\
\text { fluoranthene, fluorene, } \\
\text { naphthalene, } \\
\text { phenanthrene and } \\
\text { pyrene } \\
\text { 1-tryptophan }\end{array}$ & \\
\hline $\begin{array}{l}\text { Photoelectro- } \\
\text { chemical [25] }\end{array}$ & $\begin{array}{l}\text { Organic } \\
\text { compounds and } \\
\text { heavy metals }\end{array}$ & - & $\begin{array}{l}\text { Titanium dioxide } \\
\text { and polystyrene } \\
\text { nanoparticles }\end{array}$ & $\begin{array}{l}\text { CHI } \\
630 \mathrm{~A}\end{array}$ \\
\hline THM [27] & Trihalomethanes & 28 to $224 \mathrm{ppb}$ & $\begin{array}{l}\text { After } 24 \text {-h chlorine } \\
\text { contact time }\end{array}$ & QTF \\
\hline
\end{tabular}

current practice for genotoxicity test [63]. The THMs sensor developed by Ahmed et al. [64] is found to be fast and provides real-time monitoring, compared with the conventional practice of THMs detection that requires skilled technicians to analyze, involves the use of hazardous chemicals and does not provide real-time THM data to plant operators. It consists of a wristwatch QTF and is bound together by a polymer wire that is selective to gas-phase THMs. Different concentrations of THMs produce different ranges of resonance in the QTF.

\section{CHEMICAL DETECTION METHODS}

This section discusses the chemical detection methods such as AAS, HPLC and GC-MS.

\subsection{Atomic absorption spectroscopy (AAS)}

The AAS invention was developed in 1648 by Marcus Marci von Kronland by analyzing sunlight as it passed through water droplets creating a rainbow [67]. AAS is an analytical procedure to determine the types of metals or metalloids and their concentrations in environmental samples. It employs the absorption of optical radiation of detected metal or metalloid at its gaseous phase. The heavy metals and metalloids contamination can be found in geothermal sources, volcanic and industrial effluents from mining, petrochemical industry and landfills, resulting in pollution of the groundwater, soil and aquatic ecosystems. Analytical methods such as flame atomic absorption spectrometry, graphite furnace atomic absorption spectrometry (GFAAS), electrothermal atomic absorption 
spectrometry, inductively coupled plasma optical emission spectrometry and inductively coupled plasma mass spectrometry have been applied to direct determination of heavy metals. The GFAAS is the most sensitive technique.

\subsubsection{Application}

Analysis of arsenic was carried out in West Bengal in India and Bangladesh. Atomic absorption spectrophotometry with vapor generation assembly (AAS VGA) technique was used for the detection method on arsenic. Total arsenic analysis $[\mathrm{As}(\mathrm{III})+\mathrm{As}(\mathrm{V})]$ requires reduction of $\mathrm{As}(\mathrm{V})$ to $\mathrm{As}(\mathrm{III})$. $\mathrm{As}(\mathrm{III})$ is reduced to $\mathrm{AsH}_{3}$ vapors and finally to free As atoms, which are responsible for absorption signals in AAS. The VGA attached to AAS has acid channels filled with $10 \mathrm{M} \mathrm{HCl}$ and reduction channels with sodium borohydride. The test conditions for the reduction of the sample in the instrument were the introduction of KI in the reduction channel, along with the sodium borohydride. It is observed that the acid concentration of the sample plays an important role. Further reduction in acid concentration and analysis time is achieved for the arsenic analysis using a modified method. Analysis in both the methods is sensitive at the ppb level [68].

The levels of some heavy metals in groundwater, mixed water and wastewater in Alahsa farms, Saudi Arabia were examined. The total contents of $\mathrm{Mn}, \mathrm{Fe}, \mathrm{Cu}, \mathrm{Zn}, \mathrm{Cd}$ and $\mathrm{Pb}$ were determined using GFAAS. The level of heavy metals in groundwater and mixed water were found suitable for irrigation purposes based on the recommendation by the Food and Agriculture Organization. However, the spatial distribution study of $\mathrm{Mn}$ and $\mathrm{Fe}$ in groundwater in the area under this study was found to increase from southeast to northwest [69].

\subsubsection{Evaluation}

AAS is specifically for the identification and measurement of metals or metalloids elements and their concentrations in water samples. Different types of metals or metalloids have unique characteristics that require a certain type of AAS for its detection method. The sample preparation method has been extensively modified to ensure a good and reliable detection method via AAS.

\subsection{High-performance liquid chromatography}

LC was first used as a method of separating colored compounds by Mikhail Semenovich Tsvett in the early 20th century. In the 1970s, HPLC was introduced. HPLC consists of a reservoir mobile phase, a pump, an injector, a separation column and a detector. Compounds are separated by injecting a plug of the sample mixture onto the column. The different components in the mixture pass through the column at different rates due to differences in their partitioning behavior between the mobile liquid phase and the stationary phase [70].

\subsubsection{Application}

HPLC with UV detector is a method used for detection of HCAs in wastewater. HPLC with fluorescence detection is used to detect PAHs and also used for the analysis of pyrolytic mutagen type HCAs [71]. HCAs have UV characteristics spectra and high extinction coefficients. Therefore, these compounds can be measured with a UV detector. The UV detector is the most preferable, and HCAs can be simultaneously detected at $260-275 \mathrm{~nm}$. HCAs such as Trp-P-1 and Trp-P-2 can be detected using this UV detector. The column chromatography like tSK gel ODS-120A column that is used in HPLC provides the best peak symmetry and separation efficiency result [71-73].

Some researchers combined solid-phase extraction (SPE) with the HPLC and the UV detector and combined HPLC with fluoresce with GC and AAS. The HPLC with UV detector is a prominent 
method for analytes detection in research areas due to its frequent availability in the market and its capability of highly accurate concurrent multisamples analysis [72].

\subsubsection{Evaluation}

HPLC is one of the most powerful tools in analytical chemistry. It has the ability to separate, identify and quantify the compounds in any sample that can be dissolved in a liquid. Compounds in trace concentrations as low as parts per trillion (ppt) may easily be identified. It can accommodate larger samples along with higher molecular weight solutes through the chromatograph that would be unable to be volatilized by GC methods. HPLC is flexible because adjustment of the solvent polarity and different solvent changes can be done to find an optimum separation phase in the middle of the experiment. It is because some particular solutes in a complex solvent are very difficult (more polar) to elute and separate.

\subsection{Gas chromatography-mass spectrometry (GC-MS)}

In 1897, mass spectrometry work was carried out by Thomson and Aston at the Cavendish Laboratories, Cambridge University. GC-MS is a method that combines the features of gas liquid chromatography and mass spectrometry to identify different substances within a test sample. GC can separate volatile and semi-volatile compounds with great resolution, but it cannot identify the components. MS can provide detailed structural information on most compounds, but it cannot readily separate them. GC and MS are highly compatible techniques, which solve the above-mentioned barriers [74].

\subsubsection{Application}

A new methodology for the separation, identification and quantification of eight $\mathrm{N}$-nitrosamines was developed using raw sewage and final-discharge wastewater. The method was based on SPE and a purification technique, followed by GC analysis equipped with a triple-quadrupole MS, which gave an effective separation of the targeted compounds. The limits of the detection of this method for $\mathrm{N}$-nitrosamines ranged from 0.1 to $1.0 \mathrm{ng} \mathrm{L}^{-1}$ and the limits of quantification ranged from 0.4 to $3.3 \mathrm{ng} \mathrm{L}^{-1}$ [75].

A multiclass screening method for organic contaminants in surface water, groundwater and effluent wastewater was developed by Portoles et al. [76]. The screening is based on the use of GC-MS/time of flight, and the sample procedure involved SPE with C18 cartridges. Around 150 organic contaminants from different chemical families were investigated, including PAHs, octyl/nonyl phenols, polychlorinated biphenyls, polybrominated diethyl ethers and a notable number of pesticides and several relevant metabolites. Surface water, ground water and effluent wastewater were found to contain all target analytes at three concentration levels $\left(0.02,0.1\right.$ and $\left.1 \mu \mathrm{g} \mathrm{L} \mathrm{L}^{-1}\right)$. Influent wastewater and raw leachate from a municipal solid waste treatment plant were spiked at two levels $\left(0.1\right.$ and $\left.1 \mu \mathrm{g} \mathrm{L}^{-1}\right)$. The identification of compounds in influent wastewater was more problematic at concentrations of $0.1 \mu \mathrm{g} \mathrm{L}^{-1}$. Overall, many contaminants could be properly identified at the lowest level $0.02 \mu \mathrm{g} \mathrm{L}{ }^{-1}$ in cleaner matrices. The procedure was applied to the screening of water samples of different origins and matrix compositions, and allowed the detection of several target contaminants [76].

\subsubsection{Evaluation}

GC-MS is comparable to the HPLC. It combines the features of the GC and the MS to identify different substances within a test sample. GC-MS analysis is highly reliable if the instrument is properly maintained and the interpretation of the results is competent. 


\section{CONCLUSIONS}

The presence of carcinogens has been reported in domestic wastewater. Poor performance of sewage treatment plants causes release of these carcinogenic compounds to the surrounding watercourses. This review presented current studies on the analysis of carcinogens in wastewater through biological, physical and chemical approaches.

The biological approaches described that CA assay is faster, scientifically reliable and relatively low in cost compared with Comet assay, MN analyses, SOS chromotest and organic extraction with $\mathrm{XAD}$ and blue rayon.

As detection tools, the possession, operations and maintenance cost of these methods are the main drawback for their wide applications. The physical approaches discussed automated detections with sensors such as automated optical sensors, submersible ultraviolet fluorometer sensors, photoelectrochemical sensors and THMs sensors for the detection of carcinogenic compounds in water. These innovative sensors are portable, handy and user-friendly. However, their applicability to specific types of pollutants is the main drawback for their wide application.

Chemical methods such as AAS, HPLC and GC-MS are recommended as detection tools for research and water quality control purposes. They are practical for extensive studies and detections in the long run. The possession, operations and maintenance cost of these methods are vital.

Nevertheless, these detection methods, and their implementations, need continuation in progress, governmental enforcement and novelty, to promote a strategic research alliance for the interest of national public health.

\section{ACKNOWLEDGEMENT}

This study was supported by the Ministry of Education, Malaysia, under classification of Exploratory Research Grant Scheme (ERGS15-8200-136).

\section{REFERENCES}

[1] Weinberg, R.A., The Biology of Cancer, Garland Science, Taylor \& Francis Group, LLC: New York and UK, pp. 25-27, 2007.

[2] Kitchin, K.T., Carcinogenicity: Testing, Predicting and Interpreting Chemical Effects, Marcel Dekker: New York, NY, pp. 1-30, 1999.

[3] Wescoat, J.L. \& White, G.F., Water for Life: Water Management and Environmental Policy, The Press Syndicate of the University of Cambridge: United Kingdom, pp. 30-50, 2003.

[4] White, A. \& Rasmussen, J.B., The genotoxic hazards of domestic wastes in surface waters. Mutation Research, 410, pp. 223-236, 2007.

[5] Saxena, P.B., Chemistry of Polycyclic and Heterocyclic Compounds, Discovery Publishing House: New Delhi, pp. 13-27, 2007.

[6] Luch, A., The Carcinogenic of Polycyclic Aromatic Hydrocarbon, Imperial College Press: London, pp. 1-489, 2004.

[7] Sugimura, T., Wakabayashi, K., Nakagama, H. \& Nagao, M., Heterocyclic amines: mutagens/ carcinogens produces during cooking of meat and fish. Cancer Science, 95, pp. 290-299, 2004. doi: http://dx.doi.org/10.1111/j.1349-7006.2004.tb03205.x

[8] Clayson, D.B., Toxicological Carcinogenesis, Lewis Publishers: Boca Raton, FL, pp. 1-50, 2000.

[9] Ngadimin, N.W., Factors Influencing to the Selection of Sewage Treatment Plant, Faculty of Civil Engineering, Universiti Teknologi Malaysia: Malaysia, 2010. 
[10] Kadir, M.D.A. \& Velayutham, S., The Management of Municipal Wastewater Sludge in Malaysia, Symposium on Sludge Management, Universiti Teknologi Malaysia: Skudai, Malaysia, 1999.

[11] LaGrega, M.D., Buckingham, P.L. \& Evans, J.C., Hazardous Waste Management, McGrawHill Companies: New York, NY, pp. 1-1000, 2001.

[12] Laugesen, C.H. \& Fryd, O., Sustainable Wastewater Management in Developing Countries: New Paradigm and Case Studies From the Field, American Society of Civil Engineers: Reston, VA, 2009.

[13] Mara, D., Domestic Wastewater Treatment in Developing Countries, Earthscan: London, 2004.

[14] Arceivala, S.J. \& Asolekar, S.R., Wastewater Treatment for Pollution Control and Reuse, TataMcGraw-Hill Publishing Company: New Delhi, India, 2007.

[15] Bhunia, P.K., Optimal Design and Operation of Wastewater Treatment Plants, Civil Engineering Department, University of California: Los Angeles, CA, 1986.

[16] Sadiq, R., Rajani, B.B. \& Kleiner, Y., Risk analysis for water quality deterioration in distribution, evaluation and control of water loss in urban water networks, Valencia, Spain, June 21-25, National Research Council Canada Publication Archive, pp. 1-26, 2004.

[17] Thakur, J.S., Rao, B.T., Rajwanshi, A., Parwana, H.K. \& Kumar, R., Epidemiological study of high cancer among rural agricultural community of Punjab in Northern India. International Journal of Environmental Research and Public Health, 5, pp. 399-407, 2008. doi: http:// dx.doi.org/10.3390/ijerph5050399

[18] Koivusalo, M., Jaakkola, J.J.K., Varliainen, T., Hakulinen, T., Karialainen, S., Pukkala, E. \& Tuomisto, J., Drinking water mutagenicity and gastrointestinal and urinary tract cancers: an ecological study in Finland. American Journal of Public Health, 84, pp. 1223-1228, 1994. doi: http://dx.doi.org/10.2105/ajph.84.8.1223

[19] Kraybill, H.F., Carcinogenesis induced by trace contaminants in potable water, A Symposium on Carcinogens held by Blue Cross and Blue Shield of Greater New York, New York Academy of Medicine, 54, pp. 413-427, 1978.

[20] Zalina, A., Nik Rosmawati, N.H. \& Zaliha, I., Factors associated with preferences for safe drinking water among outpatients at Hospital Universiti Sains Malaysia (HUSM), Kelantan, Malaysia. Health and the Environment Journal, 4(1), pp. 31-41, 2013.

[21] Campbell, N.A. \& Reece, J.B., The chemistry of life (Chapter 1). The cell (Chapter 2). Genetics (Chapter 3). Mechanisms of evolution (Chapter 4). The evolutionary history (Chapter 5). Animal form and function (Chapter 7). Campbell Biology, Pearson Education Incorporation: Lake Ave, Glenview Illinois, pp. 1-800, 2009.

[22] Maluszynska, J. \& Juchimiuk. J., Plant genotoxicity: a molecular cytogenetic approach in plant bioassays. Journal of Plant Genotoxicity, 56, pp. 177-184, 2005.

[23] Fiskesjö, G., The Allium test in wastewater monitoring. Environmental Toxicology and Water Quality, 8(3), pp. 291-298, 1993. doi: http://dx.doi.org/10.1002/tox.2530080306

[24] Fiskesjö, G., The Allium test as a standard in environmental monitoring. Hereditas, 102, pp. 99-112, 1985. doi: http://dx.doi.org/10.1111/j.1601-5223.1985.tb00471.x

[25] Fenech, M., The Micronucleus assay determination of chromosomal level DNA damage. Methods Molecular Biology, 410, pp. 185-216, 2008. doi: http://dx.doi.org/10.1007/978-159745-548-0_12

[26] Ukaegbu, M.C. \& Odeigah, P.G.C., The genotoxic effect of sewage effluent on Allium cepa. Report and Opinion, 1(6), pp. 36-41, 2009. 
[27] Samuel, O.S., Osuala, F.I. \& Odeigah, P.G.C., Cytogenotoxicity evaluation of two effluents using Allium cepa assay. African Journal of Environmental Science and Technology, 41(1), pp. 21-27, 2009.

[28] Abu, N.E. \& Mba, K.C., Mutagenicity testing of pharmaceutical effluents on Allium cepa root tips meristems. Journal of Toxicology and Environmental Health Sciences, 3(2), pp. 44-51, 2011.

[29] El-Shahaby, O.A., Abdel Migid, H.M., Soliman, M.I. \& Mashaly, I.A., Genotoxicity screening of industrial wastewater using the Allium cepa chromosome aberration assay. Pakistan Journal of Biological Sciences, 6(1), pp. 23-28, 2003. doi: http://dx.doi.org/10.3923/pjbs.2003.23.28

[30] Monte Egato, L.C., Medeiros, M.D.G., Medeiros, S.R.B.D. \& Agnez-Lima, L.F., Cytotoxic and genotoxic potential of surface water from the Pitimbu river, northeastern/RN Brazil. Genetics and Molecular Biology, 30(2), pp. 435-441, 2007. doi: http://dx.doi.org/10.1590/ s1415-47572007000300023

[31] Rank, J. \& Nielsen, M.H., Genotoxicity testing of wastewater sludge using the Allium cepa anaphase-telophase chromosome aberration assay. Mutation Research/Genetic Toxicology and Environmental Mutagenesis, 418(2-3), pp. 113-119, 1998. doi: http://dx.doi.org/10.1016/ s1383-5718(98)00118-1

[32] Zeng, D.M., Li, Y. \& Lin, Q.Q., Pollution monitoring of three rivers passing through Fuzhou City, People's Republic of China. Mutation Research, 426, pp. 159-161, 1999. doi: http:// dx.doi.org/10.1016/s0027-5107(99)00061-5

[33] Grant, W.F. \& Owens, E.T., Chromosome aberration assays in Crepis for the study of environmental mutagens. Mutation Research/Reviews in Mutation Research, 410, pp. 291-307, 1998. doi: http://dx.doi.org/10.1016/s1383-5742(98)00004-0

[34] Sang, N. \& Li, G., Genotoxicity of municipal landfill leachate on root tips of Vicia faba. Mutation Research, 560, pp. 159-165, 2004. doi: http://dx.doi.org/10.1016/j.mrgentox.2004.02.015

[35] Levski, J.M. \& Singer, R.H., Gene expression and the myth of the average cell. Trends in Cell Biology, 13, pp. 4-6, 2003. doi: http://dx.doi.org/10.1016/s0962-8924(02)00002-8

[36] Mortelmans, K. \& Zeiger, E., The Ames, Salmonella/Microsome mutagenicity assay. Mutation Research, 455, pp. 29-60, 2000. doi: http://dx.doi.org/10.1016/s0027-5107(00)00064-6

[37] Beudot, C., De Me'o, M.P., Dauzonne, D., Elias, R., Laget, M., Guiraud, H., Balansard, G. \& Dume'nil, G., Evaluation of the mutagenicity and antimutagenicity of forty-two 3-substituted flavones in the Ames test. Mutation Research, 417, 141-153, 1998. doi: http://dx.doi. org/10.1016/s1383-5718(98)00103-x

[38] Černá, M., Pastorková, A., Šmíd, J., Bavorová, H., Očadlíkoví, D., Rössner P. \& Zavadil. J., Genotoxicity of industrial effluents, river waters and their fractions using the Ames test and in vitro cytogenetic assay. Toxicology Letters, 88, pp. 191-197, 1996. doi: http://dx.doi. org/10.1016/0378-4274(96)03737-x

[39] Rehana, Z., Malik, A. \& Ahmad, M., Genotoxicity of the Ganges water at Narora (U.P.), India. Mutation Research, 367, pp. 187-193, 1996. doi: http://dx.doi.org/10.1016/s01651218(96) $90076-2$

[40] Takamura-Enya, T., Watanabe, T., Tada, A., Hirayama, T., Nukaya, H., Sugimura, T. \& Wakabayashi, K., Identification of a new mutagenic polychlorinated biphenyl derivative in the Waka river, Wakayama, Japan, showing activation of an aryl hydrocarbon receptor-dependent transcription. Chemical Research Toxicology, 15, pp. 419-425, 2002. doi: http://dx.doi.org/ $10.1021 / \mathrm{tx} 010163 \mathrm{~g}$

[41] Lemos, A.T., Rosa, D.P., Rocha, J.A.V. \& Vargas, V.M.F., Mutagenicity assessment in a river basin influenced by agricultural, urban and industrial sources. Ecotoxicology and Environmental, 72, pp. 2058-2065, 2009. doi: http://dx.doi.org/10.1016/j.ecoenv.2009.08.006 
[42] Balasubramanyam, A., Sailaja, N., Mahboob, M., Rahman, M.F., Hussain, S.M. \& Grover, P., In vitro mutagenicity assessment of aluminium oxide nanomaterials using the Salmonella/ Microsome Assay. Toxicology In Vitro, 24, pp. 1871-1876, 2010. doi: http://dx.doi.org/10.1016/ j.tiv.2010.07.004

[43] White, P.A., Rasmussen, J.B. \& Blaise, C., A semi-automated, microplate version of the SOS Chromotest for the analysis of complex environmental extracts. Mutation Research, 360, pp. 51-74, 1996. doi: http://dx.doi.org/10.1016/s0165-1161(96)90237-x

[44] Ohe, T., Quantification of mutagenic/carcinogenic heterocyclic amines, MeIQx, Trp-P-1, Trp-P-2 and PhIP, contributing highly to genotoxicity of river water. Mutation Research, 393, pp. 73-79, 1997. doi: http://dx.doi.org/10.1016/s1383-5718(97)00087-9

[45] Jolibois, B. \& Guerbet, M., Evaluation of industrial, hospital and domestic wastewater genotoxicity with the Salmonella fluctuation test and the SOS chromotest. Mutation Research, 565, pp. 151-162, 2005. doi: http://dx.doi.org/10.1016/j.mrgentox.2004.10.006

[46] Ostling, O. \& Johansson, K.J., Microelectrophoretic study of radiation-induced DNA damages in individual mammalian cells. Biochemistry \& Biophysics Research Community, 123, pp. 291-298, 1984. doi: http://dx.doi.org/10.1016/0006-291x(84)90411-x

[47] Singh, N.P., McCoy, M.T., Tice, R.R. \& Schneider, E.L., A simple technique for quantitation of low levels of DNA damage in individual cells. Experiment Cell Research, 175, pp. 184-191, 1988. doi: http://dx.doi.org/10.1016/0014-4827(88)90265-0

[48] Lemos, N.G., Dias, A.L., Silva-Souza, A.T. \& Mantovani, M.S., Evaluation of environmental waters using the comet assay in Tilapia rendalli. Environmental Toxicology and Pharmacology, 19, pp. 197-201, 2005. doi: http://dx.doi.org/10.1016/j.etap.2004.03.011

[49] Rocha, P.S., Luvizotto, G.L., Kosmehl, T., Bottcher, M., Storch, V., Braunbeck, T. \& Hollert, H., Sediment genotoxicity in the Tiete River (Sao Paulo, Brazil): in vitro Comet assay versus in situ micronucleus assay studies. Ecotoxicology and Environmental Safety, 72, pp. 1842-1848, 2009. doi: http://dx.doi.org/10.1016/j.ecoenv.2009.04.013

[50] Summak, S., Aydemir, N.C., Vatan, O., Yılmaz, D., Zorlu, T. \& Bilaloglu, R., Evaluation of genotoxicity from Nilufer Stream (Bursa/Turkey) water using piscine micronucleus test. Food and Chemical Toxicology, 48, pp. 2443-2447, 2010. doi: http://dx.doi.org/10.1016/j. fct.2010.06.007

[51] Kummrow, F., Rech, C.M., Coimbrão, C.A., Roubicek, D.A. \& Umbuzeiro, G.A., Comparison of the mutagenic activity of XAD4 and blue rayon extracts of surface water and related drinking water samples. Mutation Research, 541, pp. 103-113, 2003. doi: http://dx.doi. org/10.1016/j.mrgentox.2003.07.011

[52] Oda, Y., Watanabe, T., Taro, Y., Nukaya, H. \& Wakabayashi K., Genotoxic activation of 2-phenylbenzotriazole-type compounds by human cytochrome P4501A1 and N-acetyltransferase expressed in Salmonella typhimurium umu strains. Mutation Research, 654, pp. 52-57, 2008. doi: http://dx.doi.org/10.1016/j.mrgentox.2008.04.013

[53] Malakahmad, A., Abd Manan, T.S. \& Hilmin, N., Biological procedures to detect carcinogenic compounds in domestic wastewater. WIT Transactions on Ecology and the Environment, 182, WIT Press, 2014, ISN 1743-3541, doi. 10.2495/WP140301.

[54] Tybjerg, K., Wonder-making and philosophical wonder in hero of Alexandria. Studies in History and Philosophy of Science Part A, 34(3), pp. 443-466, 2003. doi: http://dx.doi.org/10.1016/ s0039-3681(03)00053-0

[55] Herr, C.M. \& Kvan, T., Adapting cellular automata to support the architectural design process. Automation in Construction, 16(1), pp. 61-69, 2007. doi: http://dx.doi.org/10.1016/j. autcon.2005.10.005 
[56] Spear, B., James Watt: The steam engine and the commercialization of patents. World Patent Information, 30(1), pp. 53-58, 2008. doi: http://dx.doi.org/10.1016/j.wpi.2007.05.009

[57] Cat, J., On understanding: Maxwell on the methods of illustration and scientific metaphor. Studies in History and Philosophy of Science Part B: Studies in History and Philosophy of Modern Physics, 32(3), pp. 395-441, 2001. doi: http://dx.doi.org/10.1016/s1355-2198(01)00018-1

[58] Safonov, M.G., Origins of Robust control: early history and future speculations. Annual Reviews in Control, 36(2), pp. 173-181, 2012. doi: http://dx.doi.org/10.1016/j.arcontrol.2012.09.001

[59] Krotov, V.F. \& Kurzhanski, A.B., National achievements in control theory: the aerospace perspective. Annual Reviews in Control, 29(1), pp. 13-31, 2005. doi: http://dx.doi.org/10.1016/ j.arcontrol.2005.01.002

[60] Chang, T.H., Chueh, C.H. \& Yang L.K., Dynamic prediction for insufficient data roadways via automatic control theories. Control Engineering Practice, 19(12), pp. 1479-1489, 2011. doi: http://dx.doi.org/10.1016/j.conengprac.2011.08.007

[61] Alavi, S.M.M., Walsh M.J. \& Hayes M.J., Robust distributed active power control technique for IEEE 802.15.4 wireless sensor networks-a quantitative feedback theory approach. Control Engineering Practice, 17(7), pp. 805-814, 2009. doi: http://dx.doi.org/10.1016/j.conengprac.2009.02.001

[62] Dybko, A., Automated Measuring System Based on Optical Sensors for Water Analysis, XIX IMEKO World Congress Fundamental and Applied Metrology: Lisbon, Portugal, pp. 22432246, 2009.

[63] Tedetti, M., Guigue, C. \& Goutx, M., Utilization of a submersible UV fluorometer for monitoring anthropogenic inputs in the Mediterranean coastal waters. Marine Pollution Bulletin, 60, pp. 350-362, 2010. doi: http://dx.doi.org/10.1016/j.marpolbul.2009.10.018

[64] Ahmed, M.J., Zhang, B.T. \& Guo, L.H., Photoelectrochemical sensors for the rapid detection of DNA damage by some nanoparticles. Pakistan Journal Analytical Chemistry, 11(1), pp. 8-15, 2010.

[65] National Primary Drinking Water Regulations; Environmental Protection Agency, Online, http://water.epa.gov/drink/contaminants/index.cfm

[66] Kruger, K.C.C., Formation and Novel Sensing of Trihalomethanes in Drinking Water, Arizona State University: Tempe, AZ, 2007.

[67] Burns, D.T., Aspects of the development of colorimetric analysis and quantitative molecular spectroscopy in the ultraviolet-visible region. Analytical Spectroscopy Library, 2, pp. 1-19, 1987. doi: http://dx.doi.org/10.1016/b978-0-444-42880-6.50004-0

[68] Behari, J.R. \& Prakash, R., Determination of total arsenic content in water by atomic absorption spectroscopy (AAS) using vapour generation assembly (VGA). Chemosphere, 63, pp. 17-21, 2006. doi: http://dx.doi.org/10.1016/j.chemosphere.2005.07.073

[69] Assubaie, F.N., Assessment of the levels of some heavy metals in water in Alahsa Oasis farms, Saudi Arabia, with analysis by atomic absorption spectrophotometry. Arabian Journal of Chemistry, King Saud University (online), doi:10.1016/j.arabjc.2011.08.018.

[70] Heftmann, E., Chapter 2: History of chromatography and electrophoresis. Journal of Chromatography Library Part A, 22, pp. A19-A26, 1983. doi: http://dx.doi.org/10.1016/ s0301-4770(08)60863-5

[71] Kataoka, H., Methods for the determination of mutagenic heterocyclic amines and their applications in environmental analysis. Journal of Chromatography A, 774, pp. 121-142, 1997. doi: http://dx.doi.org/10.1016/s0021-9673(97)00246-x 
[72] Cassella, R.J., Sant'Anab, O.D. \& Santelli, R.E., Determination of arsenic in petroleum refinery streams by electrothermal atomic absorption spectrometry after multivariate optimization based on Doehlert design. Spectrochim Acta Part B: At Spectroscopy, 57, pp. 1967-1978, 2002. doi: http://dx.doi.org/10.1016/s0584-8547(02)00177-5

[73] Neue, U.D., HPLC Columns Theory, Technology and Practice, John Wiley \& Sons, Incorporation: New York, NY, 1997.

[74] Sharma, K.S., Mass spectrometry - the early years. International Journal of Mass Spectrometry, 349-350, pp. 3-8, 2013. doi: http://dx.doi.org/10.1016/j.ijms.2013.05.028

[75] Snyder, L.R., Kirkland, J.J. \& Dolan, J.W., Introduction to Modern Liquid Chromatography, John Wiley \& Sons, Inc: Hoboken, NJ, 2010.

[76] Portoles, T., Pitarch, E., Francisco, J.L. \& Hernandez, F., Development and validation of a rapid and wide-scope qualitative screening method for detection and identification of organic pollutants in natural water and wastewater by gas chromatography time-of-flight mass spectrometry. Journal of Chromatography A, 1218, pp. 303-315, 2011. doi: http://dx.doi. org/10.1016/j.chroma.2010.11.010

[77] National Cancer Research Institute: Comprehensive cancer information (Online), http://www. cancer.gov/cancertopics/cancerlibrary/what-is-cancer

[78] Van Delft, J.H., Van Agen, E., Van Breda, S.G., Herwijnen, M.H., Staal, Y.C. \& Kleinjans, J.C., Discrimination of genotoxic from non-genotoxic carcinogens by gene expression profiling. Carcinogenesis, 25, pp. 1265-1276, 2004. doi: http://dx.doi.org/10.1093/carcin/bgh108

[79] Hernández, L.G., Van Steeg, H., Luijten, M. \& Van Benthem, J., Mechanisms of non-genotoxic carcinogens and importance of a weight of evidence approach. Mutation Research, 682, pp. 94-109, 2009. doi: http://dx.doi.org/10.1016/j.mrrev.2009.07.002

[80] Hayashi, Y., Overview of genotoxic carcinogens and non-genotoxic carcinogens. Exp Toxicol Pathol, 44, pp. 465-471, 1992. doi: http://dx.doi.org/10.1016/s0940-2993(11)80159-4

[81] IARC, Overall evaluations of carcinogenicity: an updating of IARC Monographs, Lyon, International Agency for Research on Cancer, IARC Monographs on the Evaluation of the Carcinogenic Risk of Chemicals to Humans, Supplement 7, 1-42, p. 403, 1987.

[82] WHO Guidelines for drinking-water quality, Volume 1: Recommendations, pp. 66-68; Volume 2: Health Criteria and Other Supporting Information. WHO: Geneva, 2, pp. 185-186, 1984.

[83] A guide to the globally harmonized system of classification and labelling of chemical (GHS) (online), https://www.osha.gov/dsg/hazcom/ghs.html

[84] U.S. Department of Health and Human Services (DHHS), Public Health Service Agency for Toxic Substances and Disease Registry, Division of Toxicology/Toxicology Information, Atlanta, GA, 1995. 